\title{
Assessing soil compaction and micro-topography impacts of alternative heather cutting as compared to burning as part of grouse moor management on blanket bog
}

\author{
Andreas Heinemeyer ${ }^{\text {Corresp., } 1}$, Rebecca Berry ${ }^{2}$, Thomas J Sloan ${ }^{2}$ \\ ${ }^{1}$ Stockholm Environment Institute at the Department of Environment and Geography, University of York, York, United Kingdom \\ Department of Environment and Geography, University of York, York, United Kingdom \\ Corresponding Author: Andreas Heinemeyer \\ Email address: andreas.heinemeyer@york.ac.uk
}

Background. Over $25 \%$ of the UK land area is covered by uplands, the bulk of which are comprised of blanket bog. This not only contains most of the UK's terrestrial carbon stocks, but also represents $15 \%$ of this globally rare habitat. About $30 \%$ of UK blanket bog is managed for red grouse by encouraging ling heather (Calluna vulgaris) with rotational burning, which has been linked to habitat degradation, with reduced carbon storage and negative impacts on water storage and quality. Alternative cutting is currently being pursued as a restoration management. However, the often used heavy machinery cutting could cause considerable compaction and damage to the peat surface. Two particular issues are (i) a potential increase in bulk density reducing water storage capacity (i.e. lower pore volume and peat depth), and (ii) a possible reduction of the micro-topography due to cutting off the tops of hummocks (e.g. protruding clumps of sedges).

Methods. We set up a fully replicated field experiment assessing cutting versus burn management impacts on peat physical and surface properties. Both managements reflected commonly used grouse moor management practice with cutting using heavy tractors fitted with load distributing double wheel and tracks (lowering ground pressure), whilst burning was done manually (setting heather areas alight with flame torches). We assessed management impacts on peat depth, bulk density and peat surface micro-topography which either included pre-management measurements or plot-level data for uncut plots. Total peat depth and bulk density in four $5 \mathrm{~cm}$ sections within the top $50 \mathrm{~cm}$ was assessed. Microtopography was determined as the standard deviation of the height offsets measured over several plot transects in relation to the plot peat surface level at the start and end points of each transect.

Results. Despite an anticipated compaction from the heavy machinery used for cutting, the peat showed resilience and there was no lasting plot-level impact on either peat depth or bulk density. Notably, bulk density showed differences prior to, and thus unrelated to, management, and an overall increasing bulk density, even in uncut plots. However, cutting did reduce the plot micro-topography by about $2 \mathrm{~cm}$, mostly due to removing the tops of hummocks, whereas burnt plots did not differ from uncut plots.

Discussion. Cutting is suggested as a suitable alternative to burning on grouse moors, although compaction issues might be site specific, depending on the nature of the peat, the machinery used and impacts at resting and turning points (which were not assessed). However, any observed bulk density differences could reflect natural changes in relation to changes in peat moisture, requiring adequate experimental comparisons. Moreover, where micro-topography is a priority, cutting equipment might need to consider the specific ground conditions, which could involve adjusting cutting height and the

Peer) reviewing PDF | (2018:06:29086:2:0:NEW 23 May 2019) 
type of cutting machinery used. 
1 Assessing soil compaction and micro-topography impacts of alternative heather cutting as

2 compared to burning as part of grouse moor management on blanket bog

3 Andreas Heinemeyer ${ }^{1}$, Rebecca Berry ${ }^{2,3}$, Thomas J. Sloan ${ }^{2}$

$4{ }^{1}$ Stockholm Environment Institute, Department of Environment and Geography, University of

5 York, York, YO10 5NG, UK

$6{ }^{2}$ Department of Environment and Geography, University of York, York, YO10 5NG, UK

$7 \quad{ }^{3}$ current address: Bibury Road, Aldsworth, Cheltenham, Gloucestershire, GL54 3RD, UK

8

9

10

11 Corresponding author:

12 Andreas Heinemeyer ${ }^{1}$

13 Email address: andreas.heinemeyer@york.ac.uk 
15

\section{Abstract}

Background. Over $25 \%$ of the UK land area is covered by uplands, the bulk of which are comprised of blanket bog. This not only contains most of the UK's terrestrial carbon stocks, but also represents $15 \%$ of this globally rare habitat. About $30 \%$ of UK blanket bog is managed for red grouse by encouraging ling heather (Calluna vulgaris) with rotational burning, which has been linked to habitat degradation, with reduced carbon storage and negative impacts on water storage and quality. Alternative cutting is currently being pursued as a potential restoration management. However, the often used heavy cutting machinery could cause considerable compaction and damage to the peat surface. Two particular issues are (i) a potential increase in bulk density reducing water storage capacity (i.e. less pore volume and peat depth), and (ii) a possible reduction of the micro-topography due to cutting off the tops of hummocks (i.e. protruding clumps or tussocks of sedges).

Methods. We set up a fully replicated field experiment assessing cutting versus burn management impacts on peat physical and surface properties. Both managements reflected commonly used grouse moor management practice with cutting using heavy tractors fitted with load distributing double wheel and tracks (lowering ground pressure), whilst burning was done manually (setting heather areas alight with flame torches). We assessed management impacts on peat depth, bulk density and peat surface micro-topography which either included premanagement measurements or plot-level data for uncut plots. Total peat depth and bulk density in four $5 \mathrm{~cm}$ sections within the top $50 \mathrm{~cm}$ was assessed. Micro-topography was determined as 
36 the standard deviation of the height offsets measured over several plot transects in relation to the

37 plot peat surface level at the start and end points of each transect.

39 Results. Despite an anticipated compaction from the heavy machinery used for cutting, the peat

40 showed resilience and there was no lasting plot-level impact on either peat depth or bulk density.

41 Notably, bulk density showed differences prior to, and thus unrelated to, management, and an

42 overall increasing bulk density, even in uncut plots. However, cutting did reduce the plot micro-

43 topography by about $2 \mathrm{~cm}$, mostly due to removing the tops of hummocks, whereas burnt plots

44 did not differ from uncut plots.

45 Discussion. Cutting is suggested as a suitable alternative to burning on grouse moors, although

46 compaction issues might be site specific, depending on the nature of the peat, the machinery used

47 and impacts at resting and turning points (which were not assessed). However, any observed bulk

48 density differences could reflect natural changes in relation to changes in peat moisture,

49 requiring adequate experimental comparisons. Moreover, where micro-topography is a priority,

50 cutting equipment might need to consider the specific ground conditions, which could involve

51 adjusting cutting height and the type of cutting machinery used. 


\section{Introduction}

53 Uplands cover over $25 \%$ of the UK (Haines-Young et al., 2000). The bulk of this area comprises

54 blanket bog, dwarf-shrub heath and acid grassland. The term "blanket bog" is often used rather

55 loosely and falls within the overarching term of wetland, where conditions are such that soil

56 water-logging favours Sphagnum moss growth and peat formation such that bog development

57 covers all but the more steeply sloping ground with an average thickness of 0.5-3.0 m (JNCC,

58 1999). Moreover, the terms "mire" and "bog" are often seen as inter-changeable within the

59 context of UK blanket bog, yet are in fact complex ecosystems with quite different hydrology,

60 soil structure and plant species composition (Lindsay et al., 1988; O’Brien et al., 2007).

61 Importantly, the UK contains about 15\% of the global blanket bog areas (Tallis, 1998; Evans et

62 al., 2006), of which upland bog represents about $90 \%$ of the UK's peatland area, containing an

63 estimated 2,300 Mt of soil organic carbon (SOC) (Billett et al., 2010) whilst also providing a

64 diverse habitat for many upland plant and bird species (Bain et al., 2011). Crucially, the habitat

65 diversity, including its micro-topography (i.e. hummocks and hollows), are important in

66 supporting a range of specialist species including many in the UK rare upland birds (e.g. Stroud

67 et al., 1988). Peatlands (including the habitats bogs and dwarf shrub and heath) deliver a wide

68 range of ecosystem services (Haines-Young \& Potschin, 2008) that contribute to human well-

69 being, including climate regulation, water purification, maintenance of biodiversity, recreational

70 and educational opportunities, and tourism (Kimmel and Mander, 2010). However, many upland

71 bog areas in the UK are managed for either agriculture or sporting purposes (see chapter 5 in

72 Bain et al., 2011) with some negative impacts on ecosystem services (O’Brien et al., 2007).

73 Therefore, any detrimental management impacts on bog ecosystem functioning need to be 
74 assessed in order to advise on best practice management towards ecosystem services

75 provisioning.

76 In the UK, grouse shooting estates (i.e. red grouse; Lagopus lagopus) cover an estimated area of

$775-15 \%$, or between 0.66 to 1.7 million hectares of upland areas (Grant et al., 2012). Burning has

78 been used to manage upland vegetation in Britain for centuries and prescribed rotational burning

79 of ling heather (Calluna vulgaris) has been used to maximise grouse densities by preventing the

80 establishment of woody species and encouraging nutrient cycling, thus stimulating Calluna

81 growth and dominance (Yallop et al., 2009). This management creates a mosaic of different aged

82 stands to provide both food from new young growth and protection from predators in the taller,

83 older stands. In the UK, about $18 \%$ of peatlands (Worrall et al., 2010) and 30\% of blanket bog

84 (Natural England, 2010) are estimated to be under such a burn rotation. Although burning mostly

85 occurs on shallow peat and podzolic soils, it regularly encroaches on deeper blanket bog peat

86 areas (Yallop et al., 2005), and often peat depth is unknown to, or not necessarily taken into

87 account by, the land manager. Large scale and repeated heather burn rotations (typically $10 \%$ in

88 patches of about $0.5-1.0$ ha in size on a $10-15$ year rotation) have only been introduced across

89 the UK during the past 200 years (e.g. Hay, 2012) in relation to grouse management. However,

90 burn rotations vary regionally and shorter or longer rotations have been noted (Yallop et al.,

91 2006). Such burn rotation management encourages different age structures of heather to support

92 high grouse populations, but when done poorly or when fires get out of control, it can also kill or

93 damage the peat and bog mosses mainly responsible for maintaining peat hydrological function

94 (i.e. high water holding capacity increasing water tables and soil moisture) and therefore the

95 continued formation of peat (Natural England, 2010). 
96 As burning (largely in connection with drainage) has been considered to have contributed to

97 blanket bog degradation (Natural England, 2010), alternative management is of interest to policy

98 makers and land managers. One aspect of alternative management is reprofiling and blocking

99 drainage ditches to raise water tables and encourage 'active' bog vegetation. Moreover,

100 alternative heather management methods could also be used to reduce 'over'-domination of

101 heather in favour of more diverse and 'active' peatland forming vegetation, especially with

102 regard to the restoration of peat hydrological function and Sphagnum growth. Sphagnum is

103 recognised as a unique global carbon store, containing more carbon than any other plant genus

104 (Clymo, 1997), and is often present at a ground cover of over 80\% in peatlands (Gunnarsson, 105 2005).

During the last 25 years a significant proportion of blanket bog in the UK has undergone a

107 programme of restoration. However, most of this work focused on degraded or eroded areas

108 (mainly with grip blocking and/or re-vegetation) with little science-based evidence on the

109 implications for ecosystem processes (O’Brien et al., 2007). Even less is known about the

110 implications of current or potential alternative management options aimed at supporting 'active'

111 bog plant communities, such as heather cutting (mowing), for the heather dominated seemingly

112 'intact' (i.e. carbon accumulating) blanket bog areas on many grouse moors on which this study

113 focuses. However, as yet it remains unknown if mowing is an effective tool in reducing heather

114 dominance (e.g. requiring likely repeated mowing). Although cutting is generally more

115 expensive than burning, the sale of cut heather for commercial purposes (e.g. biomass for fuel or

116 brash for bare peat restoration) can reduce the overall cost (Backshall et al., 2001). Suitable

117 machines include specifically designed heather flails and single or double-chop forage harvesters

118 which can be attached to an all-terrain vehicle or tractor. The flail is normally set to between 
$11912.5 \mathrm{~cm}$ and $15 \mathrm{~cm}$ above the ground. A clear advantage of cutting is that this activity is much

120 less constrained by weather conditions than burning (Tucker, 2003), although access for cutting

121 machinery will be easier when conditions are drier and the ground is firmer (MacDonald, 1996).

122 However, not all areas are accessible to large scale cutting or even less so bailing equipment (i.e.

123 track width, remoteness and relief of the area and ground conditions such as very boggy or rocky

124 areas).

125 A potential benefit of cutting (with leaving brash on site) is the reduced water loss via

126 evaporation from the peat surface on brash covered ground compared to exposed burn areas, also

127 limiting any negative rain/erosion effects as indicated by a post-management only plot level

128 assessment by Worrall et al. (2013). Moreover, brash could effectively spread Sphagnum

129 propagules across larger areas, thus facilitating restoration towards 'active' bog vegetation,

130 which is the premise underlying the use of 'brashing' for restoration purposes in many areas of

131 bare peat across the UK. As tractors are often used to manage large areas of land, a particular

132 concern has been the potential impact of heavy machinery used to cut heather instead of burning

133 it. In fact, cutting has not been recommended for blanket bog where regeneration is very slow

134 and machinery could damage the vegetation (DARDNI, 2011). The two main concerns are (1)

135 compaction and (2) reducing micro-topography by chopping off the tops of hummocks. Whilst

136 compaction could cause a potential increase in bulk density reducing water storage (and reducing

137 peat depth), a possible reduction of the micro-topography due to cutting off the tops of

138 hummocks (e.g. protruding clumps of sedges) could impact surface water runoff (which is

139 slowed down by a varied micro-topography) and also affect nesting habitat for ground nesting

140 upland birds (such as Dunlin which prefer to nest within elevated hummocks). 
141 This study compared grouse moor (i.e. heather) management impacts (specifically comparing

142 burning versus cutting) on total peat depth, peat bulk density and peat surface micro-topography.

143 Three grouse moor blanket bog sites in Northern England were studied, each consisting of two

144 paired sub-catchments (burnt versus mown) with plot-level replicates for four main

145 managements (uncut, burnt, mown with or without brash removal). Management impacts were

146 compared against either pre-management measurements (i.e. all tall heather) or the uncut control

147 plots (i.e. no management). 
148 Materials \& Methods

149

150 Field sites

151 The three study sites were three active grouse moor sites in north-west England. The names used

152 to identify the sites throughout are Nidderdale, Mossdale and Whitendale (see Figure 1). The

153 sites were chosen based on a set of key criteria: all were classed as blanket bog with a mean peat

154 depth of over $1 \mathrm{~m}$ (Histosol) classified in England and Wales as Winter Hill series (see Cranfield

155 University, 2018). Typically, the sites were managed with a 10-15 year burn rotation (based on

156 gamekeeper information) and all had a long history of burning (more than 100 years; based on

157 estate information). All sites had more than 50\% Calluna vulgaris (ling heather) cover, with at

158 least some existing bog vegetation in the form of Eriophorum (cotton-grass; forming some

159 hummocks) and Sphagnum moss species, and had a low sheep stocking density of $<0.5$ ewes ha- $^{-}$

1601 . The average climatic conditions across the three sites over the period 2012-2016 (based on

161 hourly weather station data; MiniMet, Skye Instruments Ltd, Llandrindod Wells, UK) recorded a

162 mean annual temperature of $7.3^{\circ} \mathrm{C}$ and a mean annual total rainfall of $1800 \mathrm{~mm}$. The three sites

163 differed from each other, with Nidderdale in the driest, most degraded condition (with

164 considerable Hypnum jutlandicum moss cover), Whitendale supporting a vegetation which is

165 most uniformly of a 'typical bog' community though still dry and somewhat degraded, while

166 Mossdale as the wettest site showed the largest Sphagnum moss cover, though this mainly

167 reflected the presence of poor-fen vegetation characterised by Sphagnum fallax. The below Table

1681 provides an overview summary for the basic site conditions in addition to the following

169 individual site information (but also see Figure 2 for site conditions and sedge hummocks): 
171 Nidderdale is located on the Middlesmoor estate in upper Nidderdale, which lies within the

172 Yorkshire Dales National Park, UK, at 54¹0’07’N; 1 55’02’W (UK Grid Ref SE055747) about

$173450 \mathrm{~m}$ a.s.1. The site had a mean ( \pm standard deviation) annual air temperature of $7.2 \pm 0.5^{\circ} \mathrm{C}$ and

174 annual total precipitation of $1587 \pm 211 \mathrm{~mm}$, the mean annual water table depth was $-14.6 \pm 6.4$

$175 \mathrm{~cm}$. The soil is a poorly draining organic peat (Winter Hill series) with an average depth of $1.6 \pm$

$1760.3 \mathrm{~m}$ across the experimental plots with an average slope of $4 \pm 3^{\circ}$ and peat depth across the

177 catchments ranged from $0.2 \mathrm{~m}$ to $2.9 \mathrm{~m}$. Most of the grips within the study area, which were dug

178 about 40 years ago, were naturally infilled by 2010 and no further grip blocking took place

179 during the study period. There were few gullies (similar to grips but naturally formed) at this site.

Mossdale is located in Upper Wensleydale within the Yorkshire Dales National Park at 5419'01’N; 2¹7’18”W (UK Grid Ref SD813913) about $390 \mathrm{~m}$ a.s.l. The mean ( \pm standard deviation) annual air temperature was $7.2 \pm 0.5^{\circ} \mathrm{C}$ and annual total precipitation was $2029 \pm 346$ $\mathrm{mm}$, the mean annual water table depth was $-8.1 \pm 5.7 \mathrm{~cm}$. The soil is a poorly draining organic peat (Winter Hill series) with an average peat depth of $1.2 \pm 0.4 \mathrm{~m}$ at the experimental plots with an average slope of $6 \pm 3^{\circ}$ and peat depth across the catchments ranged from $0.3 \mathrm{~m}$ to $2.1 \mathrm{~m}$.

Most of the grips within the study area, which were dug about 40 years ago, were naturally infilled by 2010 . There were no gullies at this site.

Whitendale is located within the Forest of Bowland (an Area of Outstanding Natural Beauty; 
192 The mean ( \pm standard deviation) annual air temperature was $7.6 \pm 0.5^{\circ} \mathrm{C}$ and annual total

193 precipitation was $1858 \pm 308 \mathrm{~mm}$ during the five year study period, the mean annual water table

194 depth was $-8.7 \pm 6.9 \mathrm{~cm}$. The soil is a poorly draining organic peat in the Winter Hill series with

195 an average peat depth of $1.7 \pm 0.4 \mathrm{~m}$ at the experimental plots with an average slope of $8 \pm 3^{\circ}$

196 and peat depth across the entire catchment area ranged from $0.2 \mathrm{~m}$ to $4.5 \mathrm{~m}$ (i.e. with shallower

197 areas on steep slopes). This study area had no grips, although several gullies were present in both 198 catchments.

\section{Experimental design}

202

203

204

205

206

207

208

209

210

211

212

213

Each site offered two adjacent (Nidderdale and Mossdale) or closely (ca. $1 \mathrm{~km}$ ) located (Whitendale) sub-catchments at the same elevation (ca. $420 \mathrm{~m})$ and of similar size ( 10 ha), with each allocated as either burning or cutting management. The entire manipulative experiment was based on a Before-After-Control-Impact (BACI) design (Schwarz, 2015; Stewart-Oaten et al., 1986), to enable robust statistical analysis of the after management effects in relation to the experimental treatment intervention compared to pre-existing differences before management (i.e. allowing comparison to observed differences or changes unrelated to management). Within each sub-catchment four blocks each with one 5 x $5 \mathrm{~m}$ plot-level replicate per management, were defined in March 2012 with at least $50 \mathrm{~m}$ between blocks and $5 \mathrm{~m}$ between plots. Plots were marked out with wooden corner posts protruding approximately $50 \mathrm{~cm}$ from the peat surface. Water table depth was measured every 12 hours (Omnilog, WT-HR 1000, TruTrack, New Zealand) with one dipwell per plot, which was always located at the lowest corner point of the 
214 plot (to capture hydrological impacts without the need for trampling over the plot). Burning and

215 cutting (see Figure 3 for example pictures of management at the three sites) were conducted as

216 part of the usual management rotation of the grouse moors (aiming to manage heather areas

217 every 10-15 years) with typical management areas of about 0.25 ha $(50 \times 50 \mathrm{~m})$. Burning was

218 done manually with gas torches setting alight the outside of the targeted heather area, whilst

219 cutting was done using adapted tractors with double wheels (which at Mossdale were also fitted

220 with caterpillar tracks to the back wheels) to reduce ground pressure to about 2 pounds per

221 square inch (psi).

222 Figure 4 provides example pictures for the different mowing equipment used at the three sites. At

223 Nidderdale a more basic and lighter cutting machinery (a small Case International 4230 tractor,

22485 horse power, with a back-fitted simple Bomford Topper (RS18) flail) was used, compared to

225 the heavy machinery at Mossdale (a New Holland, 120 horse power, with back-fitted Major

226 hammer flails) and Whitendale (a Deutz Fahr tractor, 150 horse power, with a back-fitted heavy

227 duty Ryetec flail mower).

Table 2 provides an overview for the experimental design and sampling strategy. In the burning

229 sub-catchment (total of 4 plots per site), each block (4) contained one 5 x $5 \mathrm{~m}$ plot (FI) located

230 within a burnt area (each $\sim 0.25$ ha). In the mown catchment (total of 20 plots per site), each

231 block (4) contained five randomly allocated treatment plots (i.e. three main treatment plots and

232 two more for manual Sphagnum pellet additions) located within a mown area (each $\sim 0.25 \mathrm{ha}$ );

233 DN plots were left uncut as the 'do nothing' control, LB plots were mown with the brash left, BR

234 plots were mown with the brash removed, $\mathrm{LB}+\mathrm{Sp}$ plots were mown with the brash left and

235 Sphagnum propagules added (this treatment was part of the overall project but plots are included

236 in this analysis as they offered additional replication), $\mathrm{BR}+\mathrm{Sp}$ plots were mown with brash 
237 removed and Sphagnum propagules added. Brash was removed from BR and BR+Sp plots by

238 manual raking ( 4-5 times ca. $50 \mathrm{~L}$ brash were collected from the $5 \times 5 \mathrm{~m}$ plots in $70 \mathrm{~L}$ bags and

239 deposited in adjacent areas. Experimental management started in 2013, with burning

240 (Nidderdale: $5^{\text {th }}$ March; Mossdale: $1^{\text {st }}$ March; Whitendale: $21^{\text {st }}$ February) and cutting

241 (Nidderdale: $11^{\text {th }}$ April; Mossdale: $9^{\text {th }}$ April; Whitendale: $7^{\text {th }}$ March) on all blocks.

244 On average, vegetation was mown about $12 \mathrm{~cm}$ above the peat surface (a standard height on

245 heather-dominated grouse moors as per subcontractor and gamekeeper information) and the

246 heather brash returned to the surface was about 5-10 cm long, with the coarsest brash at

247 Nidderdale and the finest at Whitendale. However, the brash contained much finer pieces

248 containing short shoot sections, leaves and moss fragments. The initial brash layer after cutting

249 was around $5 \mathrm{~cm}$ thick. Brash was removed from mown BR and BR+Sp plots by manual raking

250 ( 4-5 times ca. $50 \mathrm{~L}$ brash were collected from the $5 \times 5 \mathrm{~m}$ plots in $70 \mathrm{~L}$ bags) and deposited in

251 adjacent mown areas outside the experimental blocks.

\section{Micro-topography}

254 The variation in the peat surface (micro-topography) was assessed on all 72 monitoring plots across the three sites in September 2015, two years after the onset of the experimental management, at Nidderdale on $14^{\text {th }}$, Mossdale on $15^{\text {th }}$ and Whitendale on $16^{\text {th }}$. An initial visual assessment after management in early spring 2013 had revealed initial compaction of the peat surface during cutting (i.e. water table dipwells were pushed down by the tractors about 15-20 
$259 \mathrm{~cm}$ into the peat) which subsequently (on the same day) rebounded (visually detectable as the

260 dipwell tube was left lower in the peat but the peat expanded again).

261 Two $60 \mathrm{~cm}$ canes were marked $20 \mathrm{~cm}$ from the bottom and notched $10 \mathrm{~cm}$ from the top. The

262 canes were inserted into the peat at a right angle to the peat surface (slopes at plot locations were

$263<5$ degrees), exactly to the $20 \mathrm{~cm}$ mark, on either side of a 5 x $5 \mathrm{~m}$ plot. A piece of twine was

264 tied tightly between the two canes so that it sat within the notches and was exactly $30 \mathrm{~cm}$ high

265 either side of the plot. The offset between peat surface and the twine was measured at nine

266 marked points (every $50 \mathrm{~cm}$ ) along the $5 \mathrm{~m}$ section of twine spanning across the $5 \mathrm{x} 5 \mathrm{~m}$ plot

267 using a $1 \mathrm{~m}$ long wooden ruler (measured to the nearest $1 \mathrm{~cm}$ ). The offset to the peat surface on

268 the mown plots with brash left was measured by pushing the measuring rod through the brash

269 layer (which was at most a few centimetres) to visually contact the peat surface. Transects

270 spanned the plots (i.e. was across the slope as opposed to down it) and there were five transects

271 per plot, with the first being $50 \mathrm{~cm}$ into the plot. This provided 45 points across each of the $5 \times 5$

272 m plots. However, in one mown plot (LB) at Nidderdale a section of 27 points could not be

273 monitored as it was not mown due to a step in the topography, and in another mown plot

$274(\mathrm{BR}+\mathrm{Sp})$ five points were excluded as they were located over a ditch. Moreover, there were

275 some missed recording points (across all plots) for Nidderdale (10) and Mossdale (1).

276 The mean offset and the standard deviation of the offsets were calculated for each plot, graphs

277 were produced and both were tested with a two-way ANOVA (management and site as factors)

278 in Microsoft Excel 2010 (Office 14). 
281 Peat depth was measured (to the nearest $0.1 \mathrm{~cm}$ with an estimated error of about $0.5 \mathrm{~cm}$ )

282 manually on all plot locations across each site in July/August 2012, before any management

283 change, and again in April 2013 shortly after the burning and cutting management. Sampling was

284 done at the same location as the water table dipwells, where the initial compaction was observed

285 immediately after mowing management. Before and after samples were obtained (peat depth) or

286 taken (for bulk density see next section) from within one area of about $25 \times 25 \mathrm{~cm}$. The tractor

287 path ran straight over this area (it was guided so both sets of wheels, front and back, moved

288 directly over the dipwell area, which therefore represented the maximum weight impact area).

289 All locations were surveyed using commercial (Clarke CHT640, Clark-Drain, Peterborough,

290 UK) $1.5 \mathrm{~cm}$ diameter PVC drainage rods (92 cm extendable sections with screw fittings) and

291 peat depth was determined (excluding hummocks) by detecting a sudden resistance (i.e. hitting

292 the bedrock/clay layer). A linear regression analysis was performed in Excel comparing pre-

293 versus post peat depths for burnt and mown areas.

\section{Bulk density}

As effects on surface compaction might not be detected in a measurement over the entire peat depth, an additional assessment of bulk density (BD) in the surface peat layers $(0-50 \mathrm{~cm})$ was undertaken and compared between pre- and post-management for the FI, DN and LB plots. For $\mathrm{BD}$ analysis a peat core was taken (see peat depth section) to $50 \mathrm{~cm}$ peat depth using a custommade three-sided $5 \mathrm{~cm}$ square box corer of $1.1 \mathrm{~m}$ length with a cutting blade (avoiding compaction and producing very consistently shaped samples of reliable volume). Peat cores were taken twice, once in August 2012 (before management), and again in March 2014 (a year after 
303

304

305

306

307

308

309

310

311

312

313

314

315

316

317

318

319

320

321

322

323

management). The peat core was separated into individual sections for which $5 \mathrm{~cm}^{3}$ samples were cut and placed in labelled storage bags. The sections sampled were: D1 (0-5 cm); D2 (10$15 \mathrm{~cm})$; D3 (20-25 cm); D4 (40-45 cm).

BD was determined on the individual $5 \mathrm{~cm}^{3}$ subsamples by first weighing individually labelled trays on a balance with a precision of $0.0001 \mathrm{~g}$. The field wet peat samples were then removed from their storage bags and place in a labelled tray. The tray was then re-weighed to allow calculation of the (wet) sample weight. Foil trays containing samples were then placed in an oven at $105^{\circ} \mathrm{C}$ to evaporate water from the samples. For extremely wet samples the oven door were left slightly ajar to let moisture escape (about 1-2 days was required). The samples were then dried completely with closed oven doors (which could take up to three days). Peat samples were dried until a constant weight was reached and stored in a desiccator until further analysis. BD was then calculated according to Chambers et al. (2011).

\section{Statistical analysis}

Regression fitting was performed in Excel (Microsoft Office v.14). All other statistics were performed in SPSS (v. 25). Micro-topography data was analysed as the standard variation (i.e. providing a measure of the magnitude or range of the plot-level micro-topography) around the mean offsets ( $\mathrm{n}=4$ per management and site) by a two-way ANOVA (with site and management as main factors). Where significant differences were detected, the Tukey HSD test was used to determine between which groups significant differences occurred. A one-sample Kolgoromov Smirnov test was used to check whether the data followed a normal distribution and a Levene's 
324 test was used to assess homogeneity of variance. Data were $\log _{10}$ transformed to fulfil the

325 assumption of a normal distribution and fulfilled the homogeneity of variance assumption. 


\section{Results}

\section{Micro-topography assessment}

329 The micro-topography (determined as the variation in peat surface across each of the $5 \times 5 \mathrm{~m}$ 330 plots across all management scenarios: burning, variations of cutting and uncut) showed that the

331 mean offset variability (measured as the standard deviation of the measured offsets against the

332 peat surface), which could be positive or negative (Figure 5), was significantly $(\mathrm{p}<0.001)$ higher

333 on burnt and uncut plots (mean of $5.8 \mathrm{~cm}$ ), and noticeably lower for all the mown plots at all

334 sites (mean of $3.8 \mathrm{~cm}$ ), but without any observable impact by brash removal or Sphagnum

335 addition (both of which required walking across the plots and therefore could have also shown

336 management related compaction). However, at Whitendale, the burnt plots had a higher

337 variability in the offset to the peat surface than the uncut plots, the latter of which were located in

338 the much flatter adjacent mown sub-catchment. Notably, the Whitendale burnt management area

339 also had more gullies across the catchment (the cause for those gullies remains unknown).

340 The micro-topography impact was also clear when shown as the median and the interquartile

341 ranges of the absolute offsets (Figure 6). Apart from the burnt plots at Whitendale, all three sites

342 had median offsets of close to zero for uncut and burnt plots, whereas mown plots had more

343 negative offsets, with lower interquartile ranges, than uncut and burnt plots, particularly for

344 Mossdale and Whitendale (apart from the offsets at burnt plots). 


\section{Peat depth assessment}

348 Overall, peat depth did not show any significant differences between pre- and post-management

349 measurements at any site, with the individual linear regression lines being very close to a 1:1 line

350 (Figure 7) for both burnt $(n=4)$ and mown with or without brash removal $(n=16$; i.e. excluding

351 uncut) plots. However, Mossdale burnt and Whitendale mown plots showed a slight tendency for

352 higher peat depths after than before management with increasing overall peat depth.

\section{Surface compaction assessment}

355 The comparison of mean BD with standard errors (SE) showed higher BD after cutting

356 management than before (Figure 8), particularly in the two upper peat layers $(0-15 \mathrm{~cm})$, at

357 Nidderdale (mean \pm SE of $0.15 \pm 0.02$ vs $0.12 \pm 0.02 \mathrm{~g} \mathrm{~cm}^{-3}$, respectively) and Mossdale (mean \pm

358 SE of $0.09 \pm 0.01$ vs. $0.07 \pm 0.01 \mathrm{~g} \mathrm{~cm}^{-3}$, respectively). However, this 'compaction' effect was

359 also observed for the burnt and uncut plots, both of which were not affected by the tractor.

360 Moreover, Whitendale peat BD, unlike those at the other two sites, were remarkably similar

361 between pre- and post-management assessments (mean $\pm \mathrm{SE}$ values for the upper two peat layers

362 on mown plots were $0.12 \pm 0.01 \mathrm{~g} \mathrm{~cm}^{-3}$ for both periods). Therefore, no further statistical

363 analysis was performed as any significant differences would have indicated a compaction effect

364 due to management although the burnt and uncut plots showed that this was clearly unrelated to

365 cutting management but rather reflected a general fluctuation in BD. 


\section{Discussion}

369 Currently, there is considerable UK government agency (i.e. Natural England) push to stop

370 rotational heather burning on deep peat as part of grouse moor management and instead replace

371 burning with alternative cutting but evidence on ecosystem physical, chemical and ecological

372 impacts of both is still limited (Harper et al. 2018). This study has provided the first data on

373 assessing potential peat physical and surface (micro-topography) implications of large scale

374 cutting as part of alternative heather-dominated blanket bog management. The machinery used

375 represented a common range of available equipment, including an estate owned small tractor

376 with double wheels and a simple flail cutter (Nidderdale) and two larger sub-contractor mowers

377 with a double chop cutter, one also with double wheels (Whitendale), the other with additional

378 caterpillar tracks (Mossdale). The double wheel and track weight distribution is important as peat

379 compaction would likely reduce peat water holding capacity and storage as seen in a review on

380 the assessment of physical impacts on water flow and storage by Rezanezhad et al. (2016). Such

381 physical compaction impacts are therefore likely to increase surface runoff via changes to the

382 hydrological conductivity of the surface peat layer (Rezanezhad et al., 2016). Moreover, the

383 cutting equipment is normally set high enough to avoid cutting hummocks and therefore

384 reducing the micro-topography of the bog (but still needs to be low enough to cut heather

385 efficiently), which has been shown to have important ecological via habitat diversity (e.g. for

386 ground nesting birds such as the in the UK quite rare dunlin or golden plover: Ratcliffe, 1990)

387 and hydrological (e.g. surface roughness and water flow/storage: Aleina et al., 2015 and

388 Nungesser, 2003) functions.

389 The micro-topography assessment did not include a pre-management change measurement.

390 However, the before-after comparison was provided by comparing the managed plots to the 
391 uncut (in this instance the control) plots, which were located within the mown area but were not

392 impacted on by the machinery. This comparison provided strong evidence that plot micro-

393 topography was made less variable, as seen in the lower offset variability on mown plots,

394 through the cutting chopping off the tops of the sedge hummocks (Figure 5). Cutting impacts

395 were slightly less at Nidderdale (when comparing the LB plots), where more basic and lighter

396 cutting machinery (a small tractor with a simple flail) was used, compared to the heavy duty

397 tractors with hammer flails and a fine double chop at Mossdale and Whitendale. Consequently,

398 the largest impact was observed in all mown treatments (across all mown plots compared to

399 burnt and uncut) for Mossdale, where the median of the absolute offset (Figure 6) was lowest,

400 and for Whitendale, where the interquartile range (Figure 6) was lowest. Whilst there were some

401 differences in peat depth and also vegetation cover between sites and burnt and mown catchment

402 plots, it is important to note that there are two comparisons to assess mowing impacts: 1) mown

403 plots vs. burnt plots (with the caveat of slightly different conditions such as in peat depth, see

404 Figure 7, yet identical NVC classification) and 2) mown vs. uncut plots (with very similar

405 conditions as placed next to each other in each block).

406 The assessment of peat depth comparing before versus after management measurements did not

407 reveal any meaningful or clear differences in relation to compaction due to cutting (Figure 7).

408 However, relatively small changes in surface peat depth could remain hidden within even a small

409 peat depth measurement error (which is estimated to be less than $5 \mathrm{~cm}$ ). Moreover, the observed

410 peat compression during cutting (of about $15 \mathrm{~cm}$, see methods) indicated the potential for a

411 lasting BD impact in the surface peat layer. Therefore the top $50 \mathrm{~cm}$ were investigated further by 412 detailed BD assessments. 
413 The observed higher BD at Nidderdale and Mossdale (Figure 8) might indicate compaction by

414 cutting machinery. However, this was the case across all managements including the burnt and

415 uncut plots, despite no tractors entering either the burnt or uncut plot areas. Therefore, the

416 observed change in BD was evidently unrelated to management and reflected a natural process of

417 BD change. A well-known natural process is "bog breathing" (Ingram, 1983) which causes peat

418 level changes due to shrinkage and expansion in relation to water table and moisture changes.

419 That this underlying natural cause explained the observed change in BD was supported by a

420 larger apparent increase in BD at the surface for both Nidderdale and Mossdale (Figure 8), which

421 could be related to differences in rainfall amounts and thus peat moisture. Whereas pre-

422 management samples were taken after a particularly wet summer period in 2012 , leading to

423 expansion and thus lower peat bulk density, post-management samples were taken after a

424 particularly dry spring in 2014 (Heinemeyer et al., unpublished climate data), leading to peat

425 shrinkage and thus higher BD. Moreover, the remarkably similar BD at Whitendale (between

426 pre- and post-management assessments) could be linked to likely similar moisture conditions in

427 relation to high rainfall events $(\sim 60 \mathrm{~mm})$ in mid-March 2014 (two weeks before post-

428 management sampling), and a further $\sim 30 \mathrm{~mm}$ of rain during the week of sampling (all

429 Heinemeyer et al., unpublished climate data), causing peat expansion and thus a decrease in BD.

430 Notwithstanding the lack of evidence on cutting causing possible micro-topography, peat depth

431 or peat compaction issues, this plot-level assessment was of low replication and did not consider

432 possible impacts elsewhere in the managed catchment area, such as stopping and turning points

433 of the heavy machinery. Moreover, this study only assessed plot-level impacts from a one-off

434 management; when heavy machinery is to be used, particularly if access is frequent, track

435 impacts would need to be addressed across the wider landscape area. Future work should assess 
436 such potential cutting impact areas, ideally also considering a broader range of blanket bog

437 conditions (i.e. impacts might be more severe on wetter, softer and more hummock containing 438 bogs). 


\section{Conclusions}

440 Despite the expected and observed initial compaction of the peat surface after cutting with heavy

441 machinery (i.e. tractors), there was no lasting effect of mowing management treatment on either

442 peat depth or bulk density. However, plot micro-topography was reduced after cutting by

443 chopping off the tops of some and mostly sedge-dominated hummocks. Further research might

444 consider wider landscape assessment of cutting equipment, particularly considering points where

445 machinery stopped and turned. 


\section{Acknowledgements}

447 We would like to thank Anda Baumerte for assistance during the field work (micro-topography

448 assessments). Thanks also to everyone involved in providing access to the three sites

449 (specifically the land owners supporting the science and the gamekeepers putting up with

450 scientists roaming the land in search for answers which seem far removed from red grouse). 


\section{References}

453 Aleina, F.C., Runkle, B.R.K., Kleinen, T., Kutzbach, L., Schneider, J. and Brovkin, V. 2015.

454 Modeling micro-topographic controls on boreal peatland hydrology and methane fluxes.

455 Biogeosciences, 12: 5689-5704.

456 Backshall, J. Manley, J. and Rebane, M. 2001. Moorland. The upland management handbook

457 (SC26), Natural England, Peterborough: 6: 1-6;130.

458 Bain, C.G., Bonn, A., Stoneman, R., Chapman, S., Coupar, A., Evans, M., Gearey, B., Howat,

459 M., Joosten, H., Keenleyside, C., Labadz, J., Lindsay, R., Littlewood, N., Lunt, P., Miller, C.J.,

460 Moxey, A., Orr, H., Reed, M., Smith, P., Swales, V., Thompson, D.B.A., Thompson, P.S., Van

461 de Noort, R., Wilson, J.D., Worrall, F. 2011. IUCN UK Commission of Inquiry on Peatlands.

462 IUCN UK Peatland Programme, Edinburgh.

463 Billett, M.F., Burden, A., Charman, D.J., Clark, J., Dinsmore, K.J., Evans, C., Evans, M.G.,

464 Jones, T., Levy, P., McNamara, N.P., Oakley, S., Ostle, N.J., Parry, L., Rowson, J.G., Ward,

465 S.E., Worrall, F. 2010. Carbon balance of UK peatlands: current state of knowledge and future

466 research challenges. Climate Research, 45: 13-29.

467 Clymo, R.S. 1997. The Roles of Sphagnum in Peatlands. Chapter 10 (pp 95-102) in: Conserving

468 Peatlands. Eds, L. Parkyn, R.E. Stoneman and H.A.P. Ingram. CAB International, Wallingford.

469 Chambers, F.M., Beilman, D.W., Yu, Z. 2011. Methods for determining peat humification and

470 for quantifying peat bulk density, organic matter and carbon content for palaeostudies of climate

471 and peatland carbon dynamics. Article 07, 1-10, http://www.mires-and-peat.net/, ISSN 1819-

$472754 X$. International Mire Conservation Group and International Peat Society. 
473 Cranfield University 2018. The Soils Guide. Available: www.landis.org.uk. Cranfield

474 University, UK. https://www.landis.org.uk/services/soilsguide/series list.cfm. [Accessed

475 September 2018].

476

477

478

479

480

481

482

483

484

485

486

487

488

489

490

491

492

DARDNI. 2011. Countryside Management Publications - Heather Moorland. Department of Agriculture and Rural Development, Northern Ireland: 1-16.

DART Computing and Smart, S. 2014. Modular analysis vegetation information system MAVIS Plot Analyser. Centre for Ecology and Hydrology. https://www.ceh.ac.uk/services/modularanalysis-vegetation-information-system-mavis [Accessed 22/01/18].

Evans, M., Warburton, J. and Yang, J.2006. Eroding blanket peat catchments: Global and local implications of upland organic sediment budgets. Geomorphology, 79(1-2): 45-57.

Grant, M.C., Mallord, J., Stephen, L. and Thompson, P.S. 2012. The costs and benefits of grouse moor management to biodiversity and aspects of the wider environment: a review. RSPB Research Report Number 43, 99 pp.

Gunnarsson, U. 2005. Global patterns of Sphagnum productivity, Journal of Bryology, 27:3, 269279, DOI: $10.1179 / 174328205 \times 70029$.

Haines-Young, R.H., Barr, C.J., Black, H.I.J., Briggs, D.J., Bunce, R.G.H., Clarke, R.T., Cooper, A., Dawson, F.H., Firbank, L.G., Fuller, R., Furse, M.T., Gillespie, M.K., Hill, R., Hornung, M., Howard, D.C., McCann, T., Morecroft, M.D., Petit, S., Sier, A.R.J., Smart, S.M., Smith, G.M., Stott, A.P., Stuart, R. and Watkins, J.W. 2000. Accounting for Nature: Assessing Habitats in the UK Countryside. DETR, London. 
493 Haines-Young, R. and Potschin, M. 2008. England's Terrestrial Ecosystem Services and the

494 Rational for an Ecosystem Approach. Full Technical Report, 89 pp. Defra (NR0107). Available 495 at:

496 http://sciencesearch.defra.gov.uk/Default.aspx?Menu=Menu\&Module=More\&Location=None\&

497 Completed $=0 \&$ ProjectID $=14751$ [Accessed September 2018].

498 Harper, A.R., Doerr, S.H., Santin, C., Froyd, C.A. and Sinnadurai, P. 2018. Prescribed fire and

499 its impacts on ecosystem services in the UK. Science of the Total Environment, 624: 691-703.

500 Hay, M. 2012. Chairman’s Comments. In: The Heather Trust, Annual Report, p. 5.

501 Ingram, H.A.P. 1983. Hydrology. In Ecosystems of the World 4A: Moors: Swamp, bog, fen and 502 moor, Gore, A.J.P. (ed), Elsevier Scientific, Amsterdam; pp.67-158.

503 JNCC. 1999. UK Biodiversity Group Tranche 2 Action Plans - Volume VI: Terrestrial and

504 Freshwater Species and Habitats. Available at: http://jncc.defra.gov.uk/PDF/UKBAP Tranche2505 ActionPlans-Vol6-1999.pdf [Accessed September 2018].

506 Kimmel, K., and Mander, U. 2010. Ecosystem services of peatlands: Implications for restoration.

507 Progress in Physical Geography, 34(4): 491-514.

508 Lindsay, R., Charman, D., Everingham, F., O'Reilly, R., Palmer, M., Rowell, T. and Stroud, D. 509 1988. The Flow Country: The Peatlands of Caithness and Sutherland. Nature Conservancy

510 Council, Peterborough, $32 \mathrm{pp}$.

511 MacDonald, A. 1996. Cutting heather as an alternative to muirburn. Information and advisory

512 note No. 58. Scottish Natural Heritage, Perth. Available at: https://www.nature.scot/information513 and-advisory-note-58-cutting-heather-alternative-muirburn [Accessed September 2018]. 
514 Morton, P.A. 2016. A Burning Issue: Assessing the impact of alternative grouse moor

515 managements on vegetation dynamics and carbon cycling on UK blanket bogs. PhD thesis,

516 University of York, UK. http://etheses.whiterose.ac.uk/17199/.

517 Natural England (2010) England's peatlands - carbon storage and greenhouse gases. Cat. Code:

518 NE257. ISBN 978-1-84754-208-3. Available at:

519 http://publications.naturalengland.org.uk/publication/30021 [Accessed September 2018].

520 Nungesser, M.K. 2003. Modelling microtopography in boreal peatlands: hummocks and hollows.

521 Ecological Modelling, 165: 175-207.

522 O’Brien, H.E., Labadz, J.C. and Butcher, D.P. 2007. Review of Blanket Bog Management and

523 Restoration. Technical report to Defra, Project No BD1241. Available at:

524 http://randd.defra.gov.uk/Document.aspx?Document=BD1241_6832_FRP.pdf [Accessed

525 September 2018].

526 Ratcliffe, D.A.1990. Bird life of mountain and upland. Cambridge University Press, Cambridge, 527 UK.

528 Rezanezhad, F., Price, J.S., Quinton, W.L., Lennartz, B., Milojevic, T. and Van Cappellen, P.

529 2016. Structure of peat soils and implications for water storage, flow and solute transport: A

530 review update for geochemists. Chemical Geology, 429: 75-84.

531 Schwarz, C.J. 2015. Analysis of BACI experiments. In: Course Notes for Beginning and

532 Intermediate Statistics. Available at:

533 http://www.http://people.stat.sfu.ca/ cschwarz/CourseNotes/ [Accessed September 2018]. 
534 Stuart-Oaten, A., Murdoch, W.W. and Parker, K.R. 1986. Environmental Impact Assessment:

535 "Pseudoreplication" in Time? Ecology, 67: 929-940.

536 Stroud, D.A., Reed, T.M., Pienkowski, M.W. and Lindsay, R.A. 1988. Birds, bogs and forestry -

537 The peatlands of Caithness and Sutherland. Eds, D.A. Ratcliffe and P.H. Oswald. Nature

538 Conservancy Council.

539 Tallis, J.H. 1998. Growth and degradation of British and Irish blanket mires. Environmental

540 Reviews, 6, 81-122.

541 Tucker, G. 2003. Review of the impacts of heather and grassland burning in the uplands on soils,

542 hydrology and biodiversity. English Nature Research Report no. 550. English Nature,

543 Peterborough, 148pp. Available at: http://publications.naturalengland.org.uk/publication/142001

$544 \quad$ [Accessed September 2018].

545 Worrall, F., Clay, G.D., Marrs, R. and Reed, M.S. 2010. Impacts of Burning Management on

546 Peatlands, Scientific Review. Report to IUCN UK Peatland Programme, Edinburgh.

547 Worrall, F., Rowson, J. and Dixon, S. 2013. Effects of managed burning in comparison to

548 vegetation cutting on dissolved organic carbon concentrations in peat soils. Hydrological

549 Processes, 27: 3994-4003.

550 Yallop, A.R., Thomas, G., Thacker, J., Brewer, T. and Sannier, C. 2005. A History of Burning as

551 a Management Tool in the English Uplands. 1: Estimates of the Areal Extent of Management

552 Burning in English Uplands. English Nature Research Report No. 667, English Nature,

553 Peterborough, 1-47. Available at: 
554 http://publications.naturalengland.org.uk/publication/59009?category=47017 [Accessed

555 September 2018].

556 Yallop, A.R., Thacker, J., Thomas, G., Stephens, M., Clutterbuck, B., Brewer, T. and Sannier, C.

557 A.D. 2006. The extent and intensity of management burning in the English uplands. Journal of 558 Applied Ecology, 43: 1138-1148.

559 Yallop A.R., Clutterbuck B. and Thacker J. 2009. Burning issues. The history and ecology of 560 managed fires in the uplands. In: Bonn A, Allott T, Hubacek K, Stewart J. Drivers of

561 Environmental Change in Uplands. Abingdon: Routledge, pp. 171-185. 


\section{Figure 1}

Field site and catchment locations to provide a geographic context.

Field site locations in north-west England (inset) in relation to the United Kingdom (outline).

Shown are the three sites Nidderdale, Mossdale and Whitendale (indicated by the red stars).

Maps downloaded: 09th September 2016 from MiniScale ${ }^{\circledR}$ [TIFF geospatial data] during

download of GB tiles from Ordnance Survey (GB) using the EDINA Digimap Ordnance Survey

Service (http://digimap.edina.ac.uk; @ Crown copyright and database rights [2016] Ordnance

Survey (100025252). The catchment boundaries (thick red lines) with the burnt (B) and

mown (M) catchments and automated weather station (blue star) are detailed in the lower

maps for Whitendale, Mossdale and Nidderdale. Note the main stream within each subcatchment and the contour lines. 


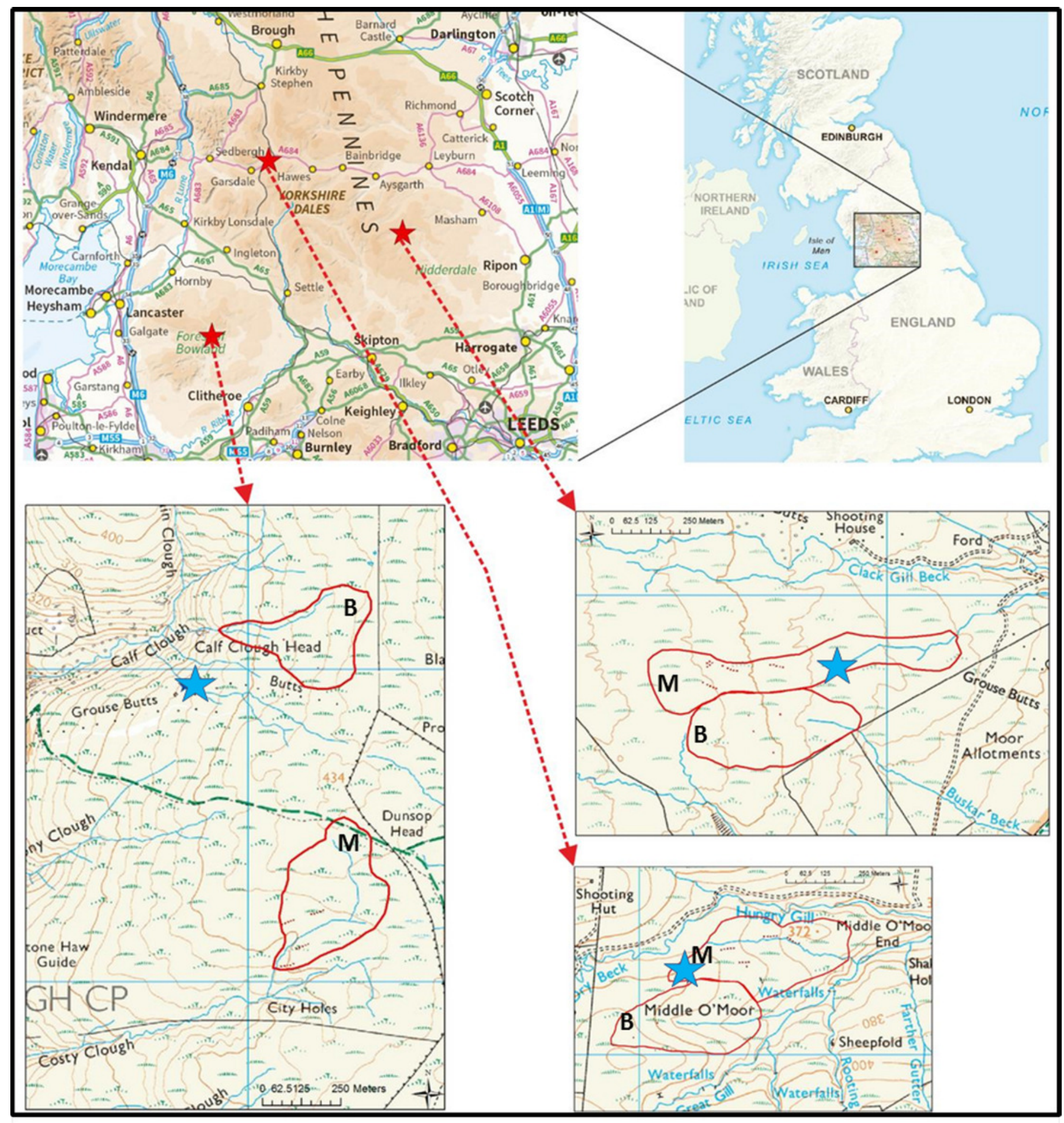




\section{Figure 2}

Site condition pictures to provide an upland blanket bog context.

Site conditions as observed by ground-level pictures (credit A. Heinemeyer) taken in winter 2012 at each site for (A) Nidderdale, (B) Mossdale and (C) Whitendale. Note the burn areas with regrowing sedge cover (mostly cotton-grass (Eriophorum spp.)) on the otherwise heather (Calluna)-dominated blanket bog vegetation.
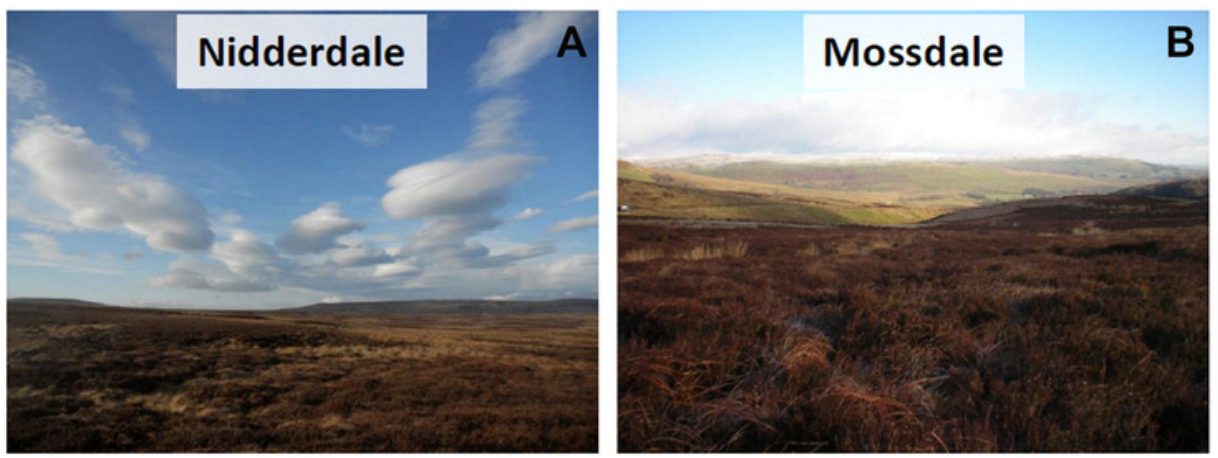

Whitendale

C

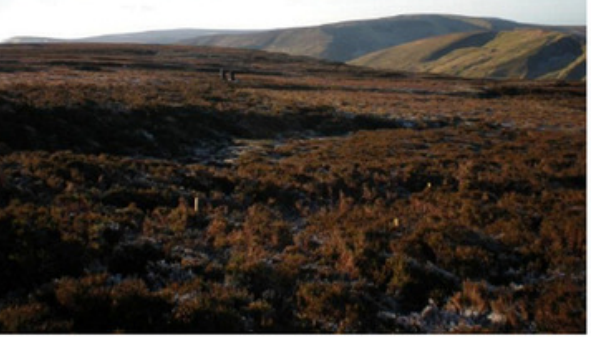




\section{Figure 3}

Site pictures providing a grouse moor management context.

The six sub-catchments (Nidderdale, Mossdale, Whitendale) shown during burning (A, B, C, respectively) and after mowing (D, E, F, respectively) in March/April 2013. For mowing machinery refer to Figure 4.

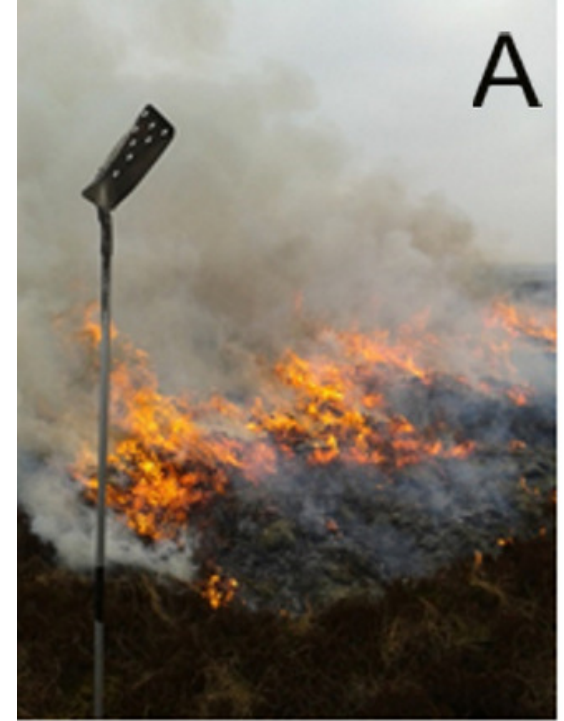

Nidderdale

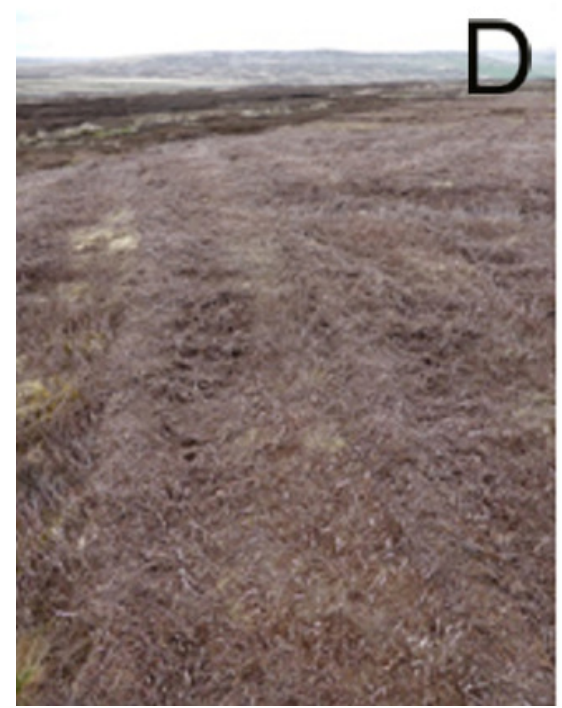

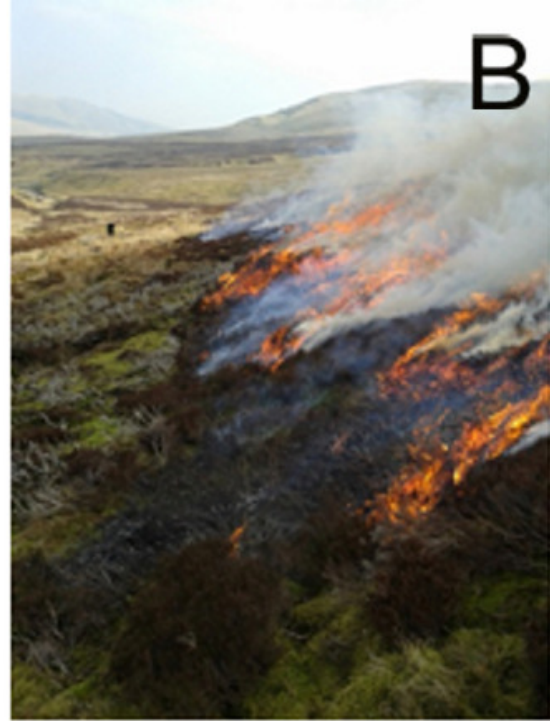

Mossdale

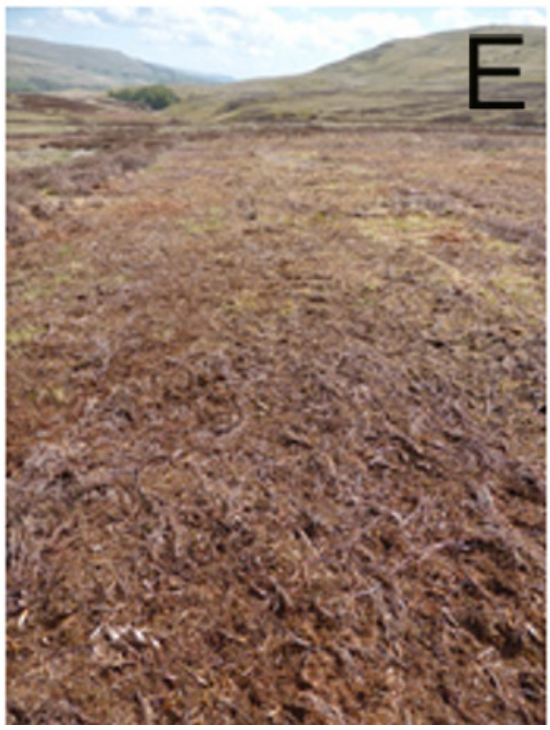

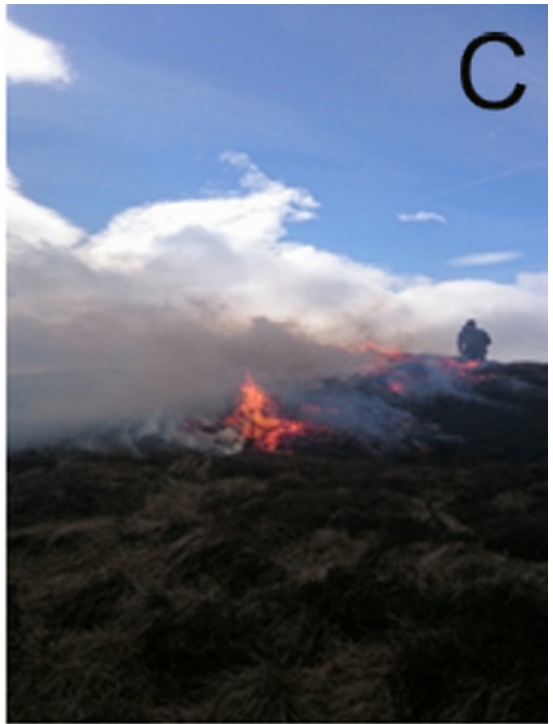

Whitendale

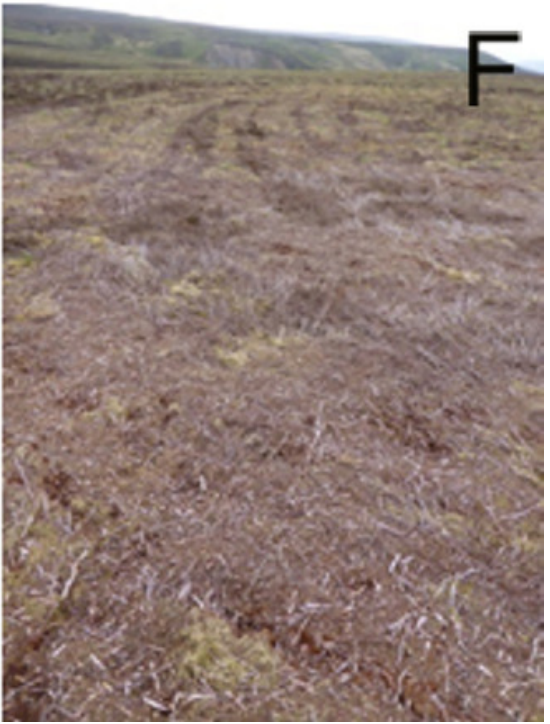




\section{Figure 4}

Site management pictures to provide a mowing context.

The three mowing arrangements: (A) Nidderdale, (B) Mossdale and (C) Whitendale. On average, vegetation was mown about $12 \mathrm{~cm}$ above the peat surface and the heather brash returned to the surface was about 5-10 cm long, with the coarsest brash at Nidderdale and the finest at Whitendale. The initial brash layer after mowing was around $5 \mathrm{~cm}$ thick.
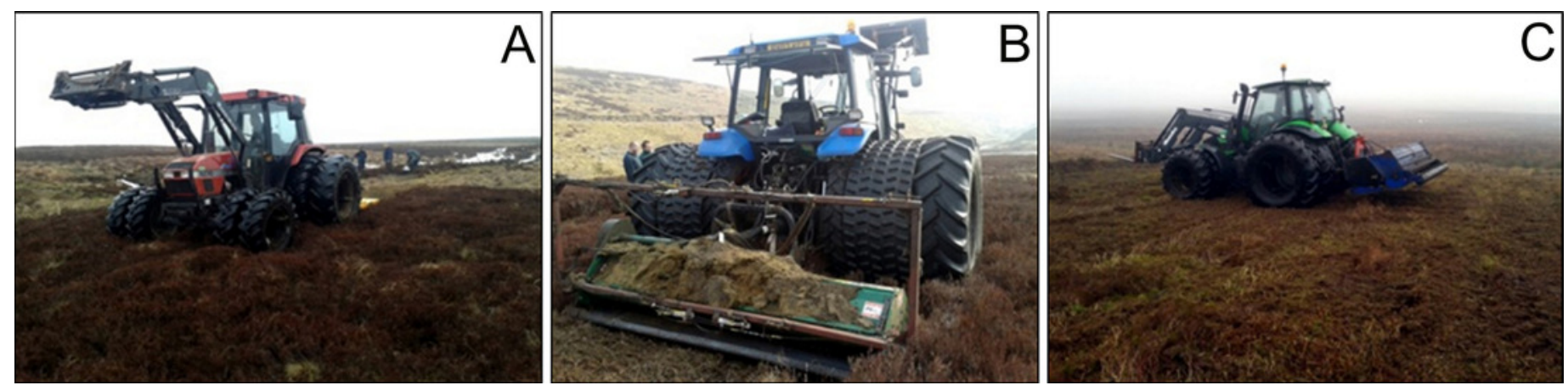


\section{Figure 5}

Micro-topography measured as the standard deviation of the measured offset $(\mathrm{in} \mathrm{cm}$ ) from the peat surface.

Mean standard deviation (STDEV \pm SE) of the measured offset (in $\mathrm{cm}$ ) in relation to the average peat surface outside the plot area obtained from the micro-topography monitoring across the $5 \times 5 \mathrm{~m}$ plots (up to 45 points were recorded per plot, see methods) for each management ( $n=4$ for burnt (FI), uncut (DN), mown with (LB) or without brash (BR) and with or without Sphagnum pellet $(+\mathrm{Sp})$ addition) for the Nidderdale, Mossdale and Whitendale blanket bog sites. The dashed black vertical line separates the burnt and uncut plots (left) from the mown plots (right), whilst the horizontal line indicates the average STDEV $(5.22 \mathrm{~cm})$ of the burnt and uncut plots across all sites.

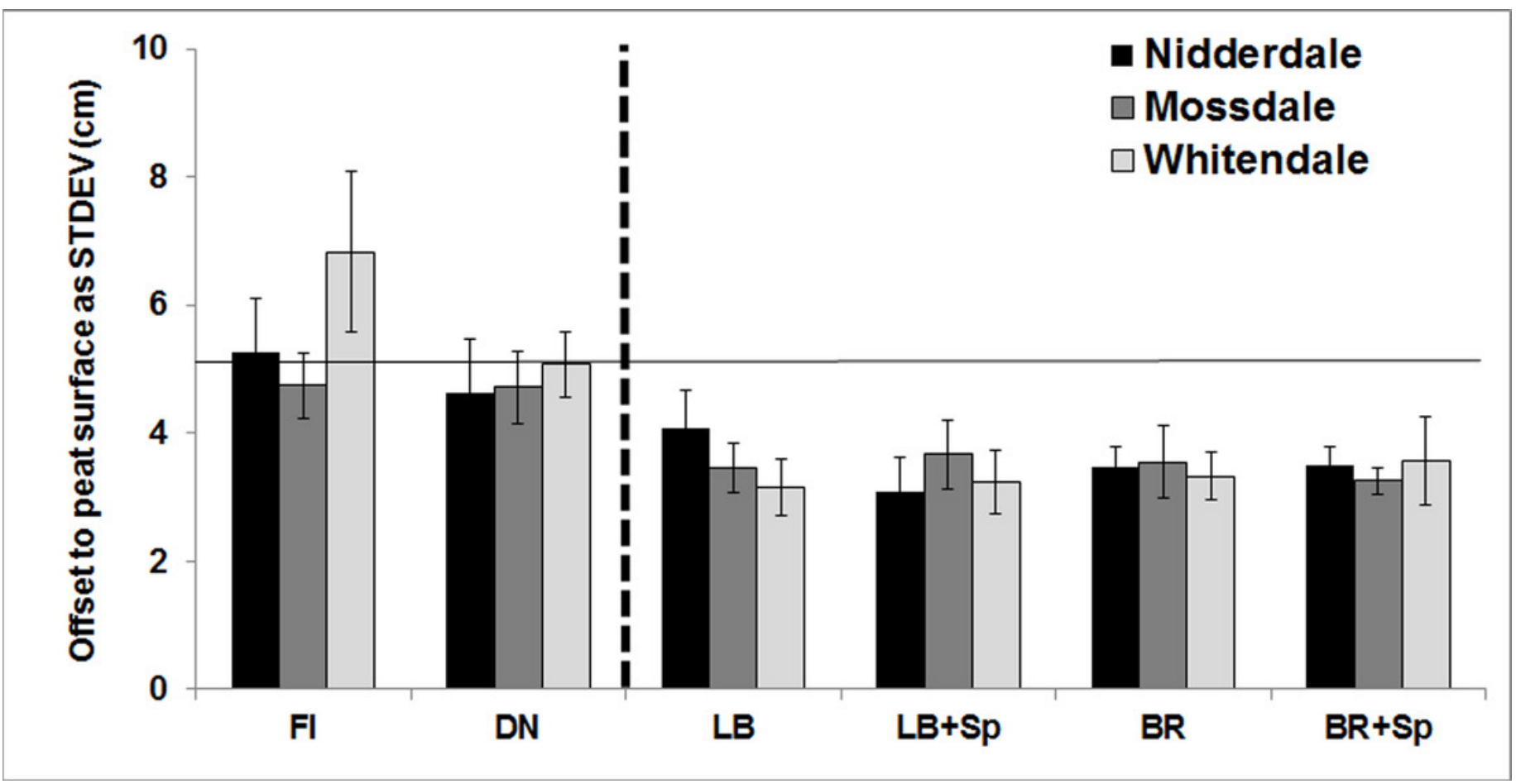




\section{Figure 6}

Micro-topography of the individual plot-level management treatments as the absolute offset (in $\mathrm{cm}$ ) in relation to the peat surface.

Mean absolute offset (in cm compared to the average peat surface (zero) outside the plot area) from the micro-topography point monitoring across the $5 \times 5 \mathrm{~m}$ plots (up to 45 points were recorded per plot, see methods) for (A) Nidderdale, (B) Mossdale and (C) Whitendale for each individual management ( $\mathrm{n}=4$ for burnt (FI), uncut (DN), mown with (LB) or without brash (BR) and with or without Sphagnum pellet (+Sp) addition). Negative values relate to dips, positive values to hummocks. Outliers are shown as + and - with median values as filled circles, the thick lines indicate the interquartile range and the thin lines are the upper and lower confidence range (1.5 times the interquartile range). 


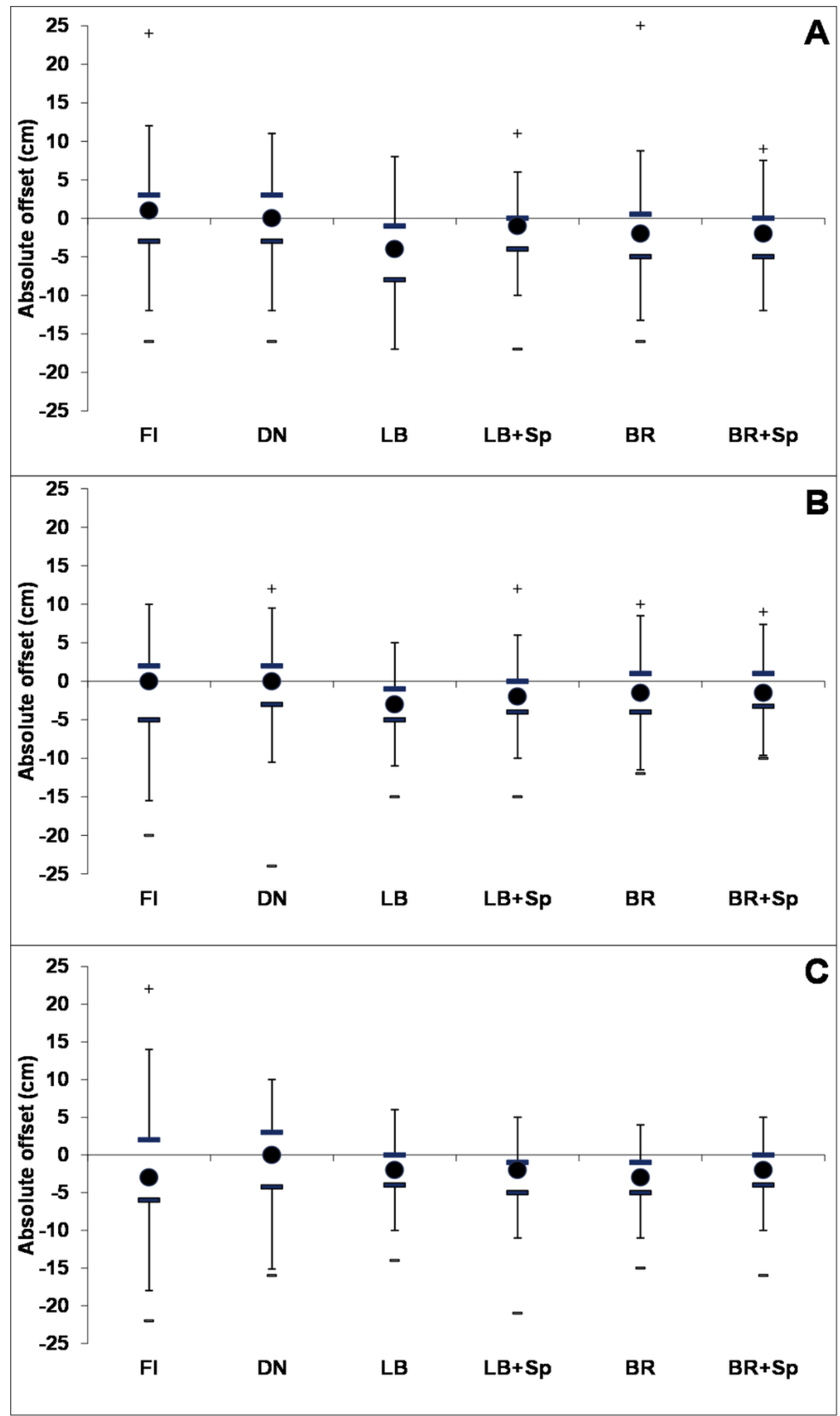




\section{Figure 7}

Mean peat depth (in $\mathrm{cm}$ ) for the mown and burnt plot-level managements at the three sites comparing the after versus before management survey depths.

Mean peat depth after plot-level management on mown (excluding uncut plots) and burnt plots plotted against mean peat depth before management for the three sites (A) Nidderdale, (B) Mossdale and (C) Whitendale. The linear regression equations and $R^{2}$ values are shown for each management (i.e. burnt vs. mown). All regressions were highly significant $(P<0.001)$ and were close to the 1:1 line (shown by a dashed line). 


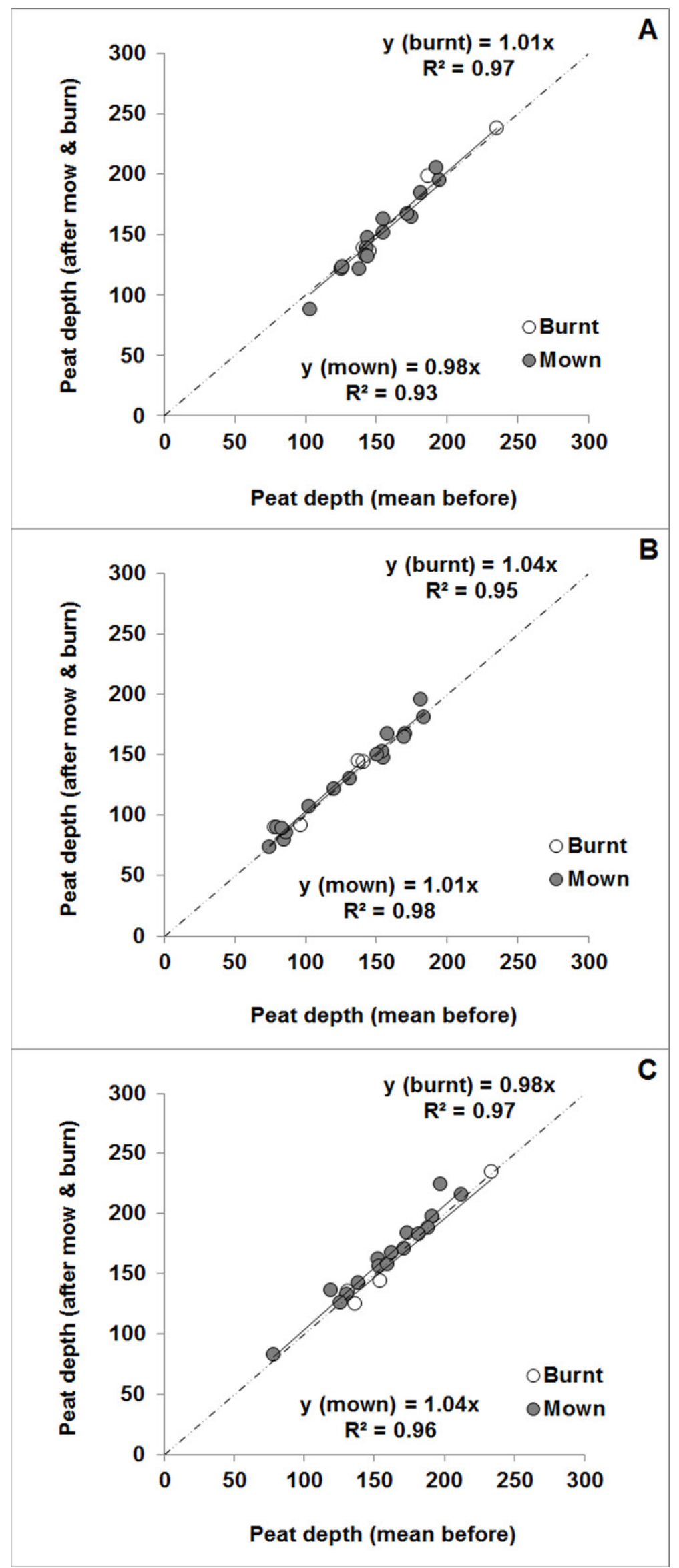

Peer] reviewing PDF | (2018:06:29086:2:0:NEW 23 May 2019) 


\section{Figure 8}

Mean bulk densities (in $\mathrm{g} / \mathrm{cm}^{3}$ ) for the burnt, uncut and mown (with brash left) plots at four soil depths comparing before versus after management survey data at the three study sites.

Mean bulk density (BD in $\mathrm{g} / \mathrm{cm}^{3}$; shown with standard error; $\mathrm{n}=4$ ) measurements after (black bars) and before management (white bars) for burnt, uncut and mown (with brash left) plots at (A) Nidderdale, (B) Mossdale and (C) Whitendale. The four investigated BD peat depth layers were: D1 $(0-5 \mathrm{~cm})$; D2 $(10-15 \mathrm{~cm})$; D3 $(20-25 \mathrm{~cm})$; D4 $(40-45 \mathrm{~cm})$. 


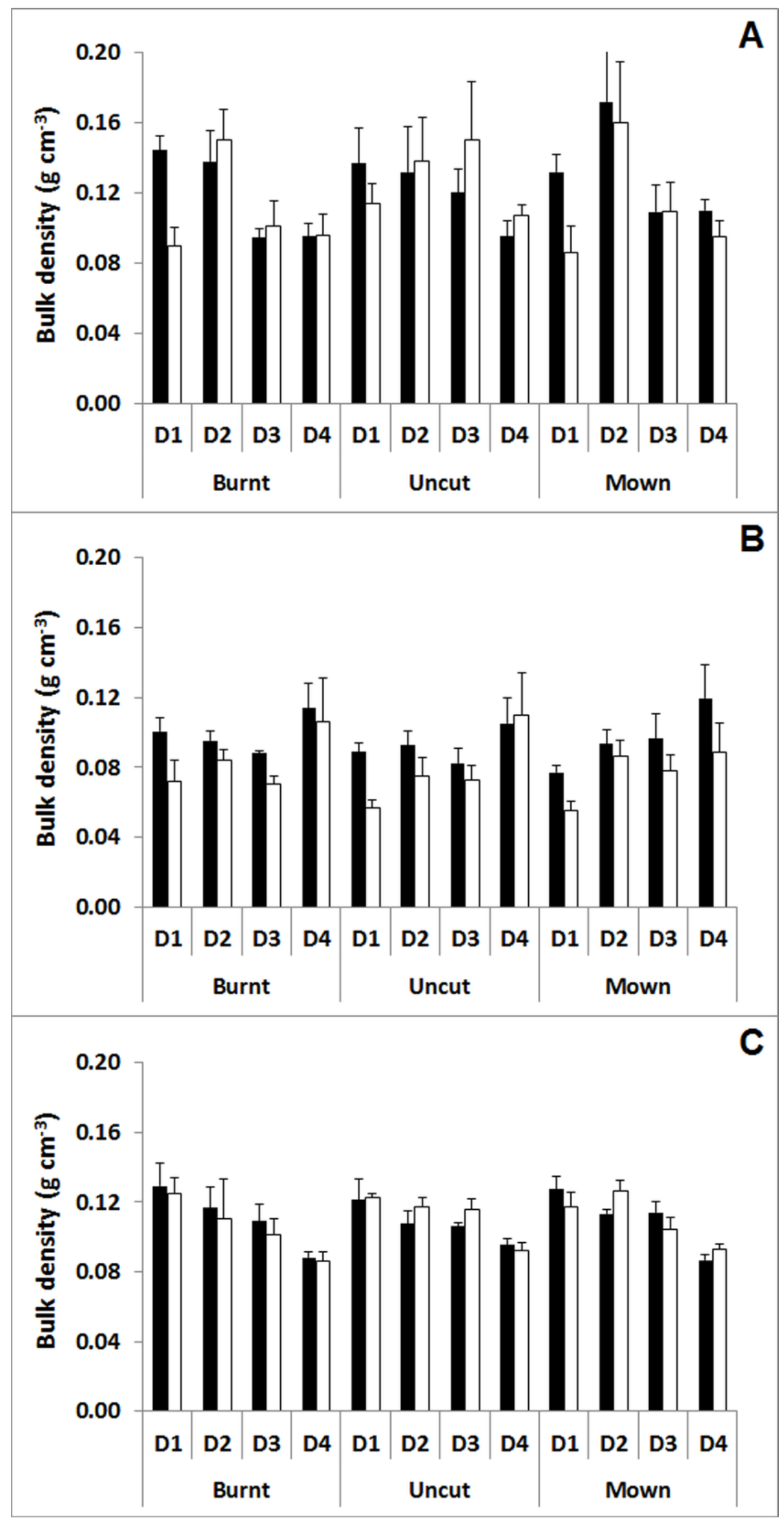

Peer] reviewing PDF | (2018:06:29086:2:0:NEW 23 May 2019) 


\section{Table $\mathbf{1}$ (on next page)}

Basic site information for the three blanket bog sites.

Basic site information for the three blanket bog sites Nidderdale, Mossdale and Whitendale. Altitude is given as metres above sea level ( $m$ a.s.l.). Climatic data are provided based on hourly weather station data from each site during 2012 - 2016 (see text for further details and standard deviations). Values in brackets indicate averages for burnt versus mown subcatchments including uncut plots). Water table depth is negative (i.e. below the surface) and vegetation class was based on the NVC classification system and was determined by additional vegetation surveys (see Morton, 2016) for each management type at each site in 2012 (pre-management) using the MAVIS software (DART Computing \& Smart, 2014). Whereas individual average annual water tables (based on monthly means) are shown, only an overall NVC category is shown as there was no difference between sites or managements. 


\begin{tabular}{|c|c|c|c|}
\hline Site & Nidderdale & Mossdale & Whitendale \\
\hline Altitude (m a.s.l.) & 450 & 390 & 410 \\
\hline Mean temperature $\left({ }^{\circ} \mathrm{C}\right)$ & 7.2 & 7.2 & 7.6 \\
\hline 2012 & 6.6 & 6.7 & 7.2 \\
\hline 2013 & 6.7 & 6.9 & 7.2 \\
\hline 2014 & 7.9 & 8.0 & 8.3 \\
\hline 2015 & 7.3 & 7.2 & 7.5 \\
\hline 2016 & 7.3 & 7.3 & 7.8 \\
\hline Mean rainfall (mm) & 1587 & 2029 & 1858 \\
\hline 2012 & 2012 & 2405 & 2209 \\
\hline 2013 & 1311 & 1708 & 1393 \\
\hline 2014 & 1512 & 1943 & 1714 \\
\hline 2015 & 1768 & 2437 & 2136 \\
\hline 2016 & 1328 & 1685 & 1839 \\
\hline Mean water table $(\mathrm{cm})$ & $-12.5(-13.2$ vs -11.9$)$ & $-7.7(-9.9$ vs -7.2$)$ & $-9.0(-8.7$ vs -9.1$)$ \\
\hline 2012 & $-14.7(-14.4$ vs -12.3$)$ & $-5.2(-8.2$ vs -6.4$)$ & $-10.3(-12.5$ vs -10.8$)$ \\
\hline 2013 & $-15.1(-11.9$ vs -11.5$)$ & $-7.3(-10.5$ vs -5.3$)$ & $-9.2(-8.2$ vs -8.7$)$ \\
\hline 2014 & $-15.3(-13.0$ vs -12.4$)$ & $-9.5(-10.9$ vs -6.9$)$ & $-9.1(-8.1$ vs -9.3$)$ \\
\hline 2015 & $-15.2(-15.0$ vs -13.5$)$ & $-7.5(-10.0$ vs -5.1$)$ & $-9.4(-10.5$ vs -9.8$)$ \\
\hline 2016 & $-12.6(-12.0$ vs -9.8$)$ & $-10.2(-9.6$ vs -7.5$)$ & $-5.8(-5.4$ vs -8.7$)$ \\
\hline Plot-level peat depth (m) & $1.6(1.8$ vs 1.5$)$ & $1.2(1.1$ vs 1.3$)$ & $1.7(1.6$ vs 1.7$)$ \\
\hline Plot-level slope $\left(^{\circ}\right)$ & $4(3$ vs 6$)$ & $6(5$ vs 7$)$ & $8(6$ vs 11) \\
\hline $\begin{array}{r}\text { Vegetation type; } \\
\text { NVC class }\end{array}$ & \multicolumn{3}{|c|}{$\begin{array}{l}\text { Erica tetralix sub-community of the Calluna vulgaris - Eriophorum } \\
\text { vaginatum blanket mire community; M19a }\end{array}$} \\
\hline
\end{tabular}




\section{Table 2 (on next page)}

Description of the experimental design and sampling strategy.

Summary of the experimental design and sampling strategy across the three blanket bog sites. Numbers in brackets are the number of replicates or sampling strategies. Individual plot treatments had four replicates $(n=4)$, one in each of four blocks within each subcatchment. See main text for further details. 


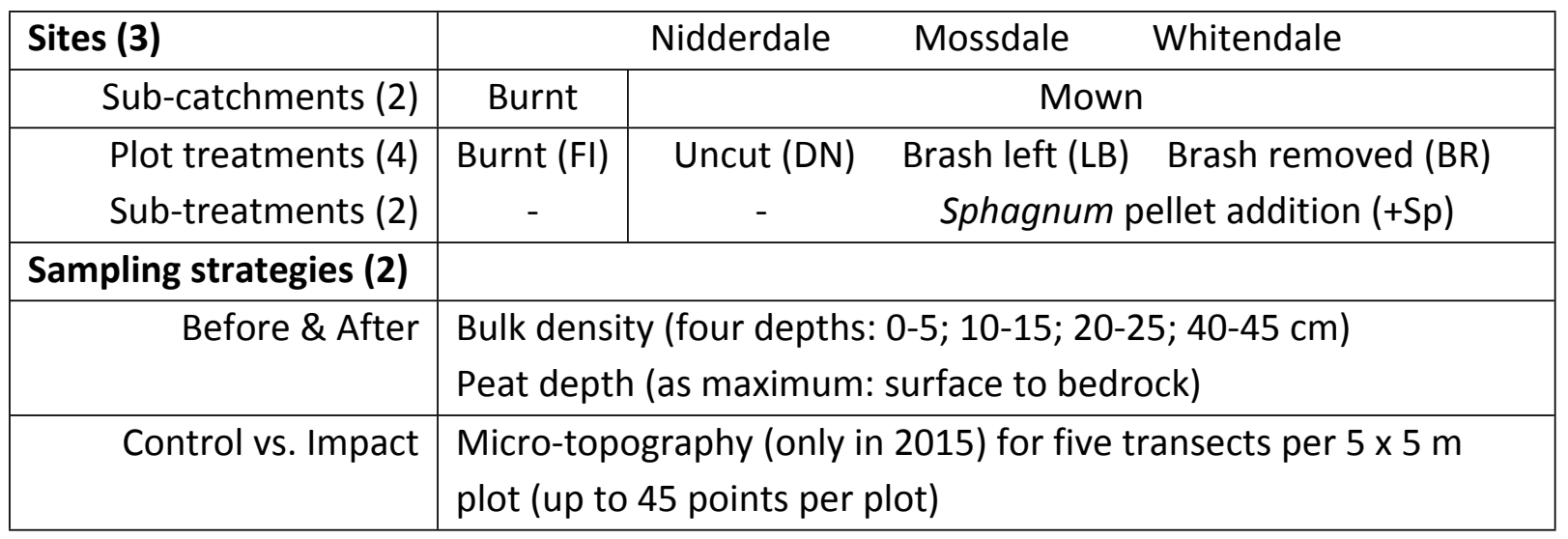

1 